\title{
Study on the influence of Mineral Admixtures on Aerated Light Weight Concrete
}

\author{
Sabarinath $\mathrm{R}^{1}$, Indu Susan Raj ${ }^{2}$, Dr. Elson John ${ }^{3}$ \\ ${ }^{I}$ Dept. of Civil Engineering, Mar Athanasius College of Engineering, Kerala, India \\ ${ }^{2}$ Asst. Professor, Dept. of Civil Engineering, Mar Athanasius College of Engineering, Kerala, India \\ ${ }^{3}$ Professor, Dept. of Civil Engineering, Mar Athanasius College of Engineering, Kerala, India
}

\begin{abstract}
Aerated light weight concrete (ALC) has gained tremendous popularity in years owing to its sustainability, density, low thermal conductivity and use of less mortar joints. The objective of this study is to develop a good performance aerated concrete to provide a better alternative than commercially available concrete blocks for structural applications of masonry. Use of different mineral admixtures enhances towards better strength and low density ranges. In particular, the mechanical behaviour of ALC cubes and blocks under pure compression with and without different admixtures is investigated. Test results indicate that the addition of admixtures improved the compressive strength up to $44.5 \%$ for $25 \%$ and $30 \%$ volume fraction of mineral admixtures. Similarly, it resulted in 5\% reduction of densities by addition of 25\% and $30 \%$ volume fraction of mineral admixtures respectively.
\end{abstract}

Keywords: Aluminium powder (Al), Light weight Concrete, Fly ash (FA), Granulated slag (GGBS), Compressive Strength.

\section{Introduction}

Light weight concrete is an important and versatile material in modern construction. It has many and varied applications including multistorey building frames and floors, bridges, offshore oil platforms, and prestressed or precast elements of all types. Many architects, engineers, and contractors recognize the inherent economies and advantages offered by this material, as evidenced by the many impressive lightweight concrete structures found today throughout the world. Structural light weight concrete solves weight and durability problems in buildings and exposed structures. Light weight concrete has strengths comparable to normal weight concrete, yet is typically $25 \%$ to $35 \%$ lighter. Lightweight concrete precast elements offer reduced transportation and placement costs. Light weight concrete has density less than conventional concrete that is less than $1800 \mathrm{Kg} / \mathrm{m}^{3}$. The main advantage is its strength to weight ratio as compared to conventional concrete. Thus it reduces the dead load of the structure, which will in turn reduce the structural elements and the steel reinforcement. It also possesses enhanced steel reinforcement and sound insulation properties.

An additive or admixtures are also called supplementary cementing materials. It enhances the properties of concrete in fresh and hardened states. They can be used with Portland cement either individually or in combinations. Mineral admixtures affect the nature of the hardened concrete through pozzolanic activity. Though their contribution to early strength is less they considerably increase the later strength. Use of mineral admixtures in concrete results in cost and energy savings as replacement of cement leads to cost savings and energy required to process these materials is also much lower than cement. Environmental damage and pollution is minimized by the use of these by-products. The different mineral admixtures mainly used are fly ash, silica fume, metakaolin and ground granulated blast furnace slag. Mineral admixtures been used in this work are fly ash and Ground Granulated Blast furnace Slag (GGBS).

This paper intends to study the influence of mineral admixtures on aerated light weight concrete

\subsection{Materials}

\section{Experimental programme}

Cement used for project work is Ordinary Portland Cement of 53 grade. Table 1 and Table 2 shows the properties of cement and fine aggregate used. M-Sand is used as the fine aggregate. Table 3 shows the chemical composition of air entraining agent used in the work.

Table 1. Properties of cement

\begin{tabular}{|c|c|c|}
\hline Properties & Value & Codal Values \\
\hline Specific gravity & 3.12 & $3.12-3.14$ \\
\hline Standard consistency & $30 \%$ & $26-33 \%$ \\
\hline Initial setting time & $65 \mathrm{~min}$ & $>30 \mathrm{~min}$ \\
\hline Final setting time & More than $3 \mathrm{hrs}$ & $<600 \mathrm{~min}$ \\
\hline
\end{tabular}




\begin{tabular}{|c|c|c|}
\hline Fineness & $<10 \%$ & $<10 \%$ \\
\hline Average cube compressive Strength $(\mathrm{MPa})$ & 53.5 & 53 \\
\hline
\end{tabular}

Table 2. Physical properties of Fine Aggregate

\begin{tabular}{|c|c|}
\hline Properties & Value \\
\hline Specific gravity & 2.59 \\
\hline Water absorption & $12 \%$ \\
\hline Fineness modulus & 3.787 \\
\hline Grading zone & Zone II \\
\hline
\end{tabular}

Table 3. Chemical composition of Aluminium powder

\begin{tabular}{|c|c|c|}
\hline Assay & Minimum & $99.50 \%$ \\
\hline Arsenic $(\mathrm{As})$ & Minimum & $0.0005 \%$ \\
\hline Lead $(\mathrm{Pb})$ & Minimum & $0.03 \%$ \\
\hline Iron $(\mathrm{Fe})$ & Minimum & $0.50 \%$ \\
\hline
\end{tabular}

\subsection{Methodology}

In the present investigation aerated concrete mixes of $1: 1$ by weight of cement and sand with water cement ratio of 0.45 were used throughout the tests of mortar mix. Six proportions of aluminium powder $(0.1$, $0.25,0.5,0.75,1,2 \%$ ) by weight of cement are used for partial replacement of cement and four proportions of admixtures $(15,20,2530 \%)$ by weight of cement were used. For making concrete blocks 1:1 and 1:2 proportions of cement:sand are used with percentage replacement of aluminium powder are $(0.25$ and $0.5 \%)$ and admixture are (25\%) by weight of cement.

\subsection{Test setup}

Typical mortar cubes of size $70.7 \times 70.7 \times 70.7 \mathrm{~mm}$ and $150 \times 150 \times 150 \mathrm{~mm}$ were used. Blocks for aerated concrete are made by $300 \times 200 \times 150 \mathrm{~mm}$ specimens. All the cubes and blocks were subjected to compressive test and density check at every 7 day, 28 day and 56 day. Also a thermal study and water absorption test was done.

\section{Test Results}

On addition of $\mathrm{Al}$ powder, the aerated concrete specimens showed significant reduction in compressive strength. Thus reduction increases with increasing percentage of $\mathrm{Al}$ powder and the compressive strength is very low when the percentage of $\mathrm{Al}$ powder reaches above $2 \%$ by weight of cement. Thus comparing the values, optimum dosage of air entraining agent is been optimized as $0.5 \%$ by weight of cement. Figure 1 shows the variation of 3, 7 and 28 day compressive strength of mortar cubes with different percentages of Al powder.

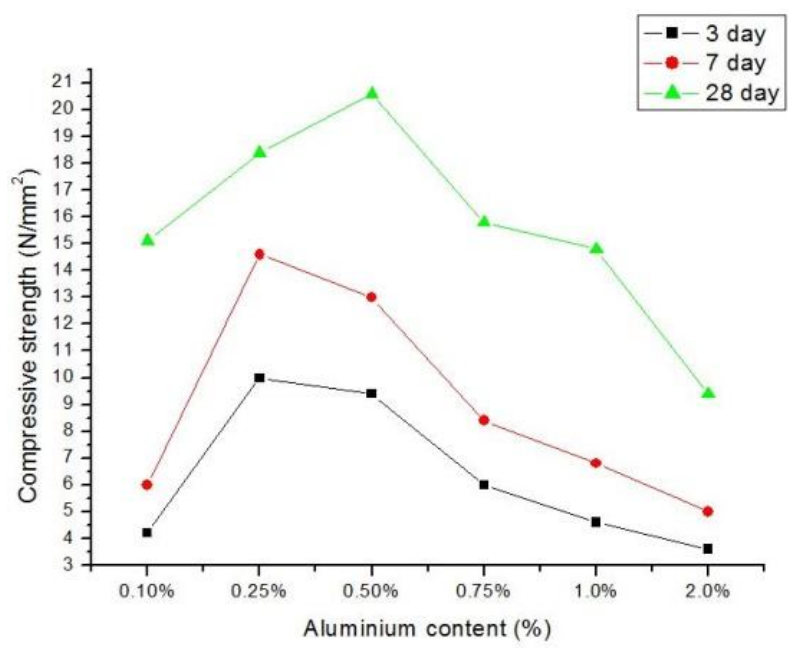

Fig 1. Variation of compressive strength with varying percentages of $\mathrm{Al}$ powder

\subsection{Density}

Table 4 shows the values of dry densities for ALC specimens produced by using 0.5 percentage (optimized dosage) of $\mathrm{Al}$ powder with different percentages of admixtures. Results shows that the dry densities of aerated concrete decreases with the increase of the percentage of admixtures 
Table 4. Comparison of densities of ALC with various percentages of admixtures

\begin{tabular}{|c|c|c|c|c|c|}
\hline \multirow[t]{2}{*}{ Mix } & \multirow[t]{2}{*}{ Al (\%) } & \multirow[t]{2}{*}{ Admixture (\%) } & \multicolumn{3}{|c|}{ Dry Density $\left(\mathrm{kg} / \mathrm{m}^{3}\right)$} \\
\hline & & & 7 days & 28 days & 56 days \\
\hline A1F1 & \multirow{4}{*}{$0.5 \%$} & $15 \% \mathrm{FA}$ & 1774 & 1718 & 1712 \\
\hline $\mathrm{A} 1 \mathrm{~F} 2$ & & $20 \% \mathrm{FA}$ & 1765 & 1710 & 1708 \\
\hline A1F3 & & $25 \% \mathrm{FA}$ & 1757 & 1701 & 1698 \\
\hline A1F4 & & $30 \% \mathrm{FA}$ & 1747 & 1694 & 1691 \\
\hline A1G1 & \multirow{4}{*}{$0.5 \%$} & $15 \%$ GGBS & 1754 & 1665 & 1658 \\
\hline A1G2 & & $20 \%$ GGBS & 1745 & 1658 & 1651 \\
\hline A1G3 & & $25 \%$ GGBS & 1735 & 1649 & 1638 \\
\hline A1G4 & & $30 \%$ GGBS & 1728 & 1644 & 1640 \\
\hline
\end{tabular}

\subsection{Compressive strength}

The compressive strength test results are presented in Table 5. Fig 3 shows the relationships between compressive strength of aerated concrete and the percentage of admixture contents. It is clear that the compressive strength increases with the increase in percentage of admixture content

Table 5. Comparison of Compressive strength of ALC with various percentages of admixtures

\begin{tabular}{|c|c|c|c|c|c|}
\hline \multirow{2}{*}{ Mix } & \multirow{2}{*}{ Al (\%) } & \multirow{2}{*}{ Admixture (\%) } & \multicolumn{3}{|c|}{ Compressive strength $\left(\mathrm{N} / \mathrm{mm}^{2}\right)$} \\
\hline & & & 7 days & 28 days & 56 days \\
\hline A1F1 & \multirow{4}{*}{$0.5 \%$} & $15 \% \mathrm{FA}$ & 9 & 18.5 & 22 \\
\hline A1F2 & & $20 \% \mathrm{FA}$ & 13.2 & 20.2 & 24.7 \\
\hline A1F3 & & $25 \% \mathrm{FA}$ & 14.7 & 26 & 28.2 \\
\hline A1F4 & & $30 \% \mathrm{FA}$ & 11.6 & 21 & 24.3 \\
\hline A1G1 & \multirow{4}{*}{$0.5 \%$} & $15 \%$ GGBS & 11 & 18 & 20.4 \\
\hline A1G2 & & $20 \%$ GGBS & 12 & 18.6 & 22.5 \\
\hline A1G3 & & $25 \%$ GGBS & 10.7 & 19.8 & 26 \\
\hline A1G4 & & $30 \%$ GGBS & 9.5 & 20.4 & 23.6 \\
\hline
\end{tabular}

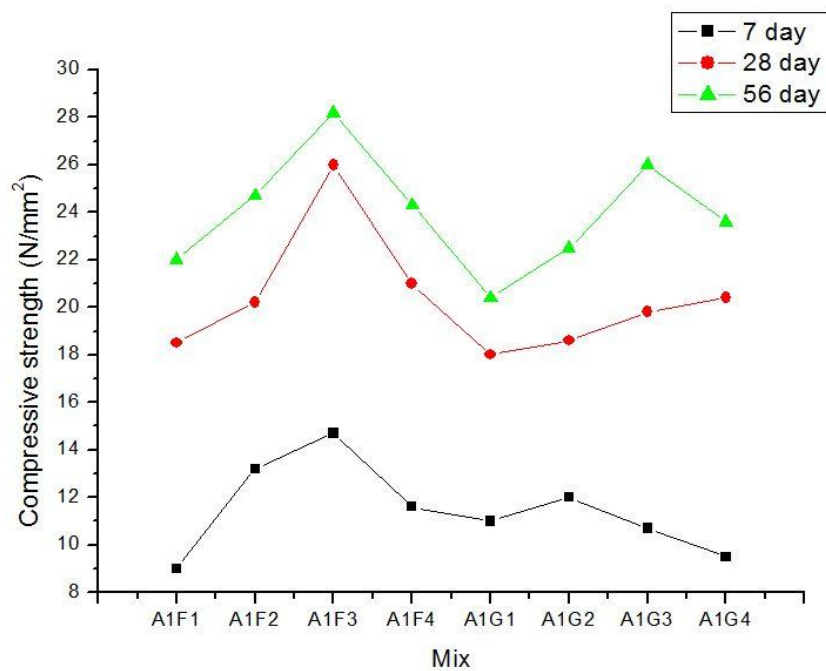

Fig 2. Comparative study of compressive strength of aerated cubes with partial replacement of cement with admixtures

Thus test results indicate that the addition of admixtures improved the compressive strength up to $45 \%$ for $25 \%$ and $30 \%$ volume fraction of mineral admixtures. Similarly, it resulted in $5 \%$ reduction of densities by addition of $25 \%$ and $30 \%$ volume fraction of mineral admixtures respectively.

\subsection{Thermal Study}

In this experimental study the cubes made with various admixtures subjected to elevated temperature and those at ambient temperatures were compared. The compressive strength results of both were recorded. The admixture content in aerated light weight concrete was confined to $25 \%$ replacement. The specimens were subjected to a temperature of $150^{\circ} \mathrm{C}$ 
Table 6 Comparison of Compressive Strength with various Mixes

\begin{tabular}{|c|c|c|c|}
\hline \multicolumn{4}{|c|}{ Cement : sand = 1:1 } \\
\hline \multirow[t]{2}{*}{ Mix } & \multirow{2}{*}{$\begin{array}{c}\text { Temperature }\left(^{\circ}\right. \\
\text { C) }\end{array}$} & \multicolumn{2}{|c|}{ Compressive strength at various duration $\left(\mathrm{N} / \mathrm{mm}^{2}\right)$} \\
\hline & & $2 \mathrm{hr}$ & $4 \mathrm{hr}$ \\
\hline \multirow[t]{2}{*}{ A3F3 } & 28 & \multicolumn{2}{|c|}{18.51} \\
\hline & 150 & 19.4 & 21.1 \\
\hline \multirow[t]{2}{*}{ A3G3 } & 28 & \multicolumn{2}{|c|}{19.47} \\
\hline & 150 & 20.2 & 21.9 \\
\hline
\end{tabular}

From Tables 6 and 7, it was observed that the rise in temperature didn't bring about any strength deterioration. The temperature rise had a positive effect on the compressive strength of aerated cubes. Moreover, the aerated cubes exhibited good resistance at a temperature of $150^{\circ} \mathrm{C}$. The higher resistance of the aerated cubes can be explained by the lower coefficient of thermal expansion.

Table 7 Comparison of Compressive Strength with various Mixes

\begin{tabular}{|c|c|c|c|}
\hline \multicolumn{4}{|c|}{ Cement : sand = 1:2 } \\
\hline \multirow[t]{2}{*}{ Mix } & \multirow{2}{*}{$\begin{array}{c}\text { Temperature }\left(^{\circ}\right. \\
\text { C) }\end{array}$} & \multicolumn{2}{|c|}{ Compressive strength at various duration (N/mm²) } \\
\hline & & $2 \mathrm{hr}$ & $4 \mathrm{hr}$ \\
\hline \multirow[t]{2}{*}{ A3F3 } & 28 & \multicolumn{2}{|c|}{15.45} \\
\hline & 150 & 16.11 & 16.42 \\
\hline \multirow[t]{2}{*}{ A3G3 } & 28 & \multicolumn{2}{|c|}{14.89} \\
\hline & 150 & 15.34 & 15.88 \\
\hline
\end{tabular}

Based on the above results, ALC blocks were finally made having $0.5 \% \mathrm{Al}$ content and $25 \% \mathrm{FA}$ or GGBS. ALC blocks were made out for both 1:1 and 1:2 cement to sand ratios. And finally an overall comparison study was done with commercially available blocks also.

Table 6. Properties of ALC blocks prepared using the study results

\begin{tabular}{|c|c|c|c|c|}
\hline \multirow{2}{*}{$\begin{array}{c}\text { Cement:sand } \\
\text { ratio }\end{array}$} & \multicolumn{2}{|c|}{ Dry density $\left(\mathbf{K g} / \mathbf{m}^{\mathbf{3}}\right)$} & \multicolumn{2}{c|}{ Compressive strength $\left(\mathbf{N} / \mathbf{m m}^{2}\right)$} \\
\cline { 2 - 5 } & $\mathbf{7}$ day & $\mathbf{2 8}$ day & $\mathbf{7 ~ d a y}$ & $\mathbf{2 8}$ day \\
\hline $1: 1$ & 1658 & 1618 & 6.1 & 10.8 \\
\hline $1: 2$ & 1663 & 1614 & 4.8 & 7.8 \\
\hline
\end{tabular}

Table 7. Comparison of properties of ALC blocks with commercially available blocks

\begin{tabular}{|c|c|c|c|}
\hline \multicolumn{1}{|c|}{ Blocks } & $\begin{array}{c}\text { Dry density } \\
\left(\mathbf{K g} / \mathbf{m}^{3}\right)\end{array}$ & $\begin{array}{c}\text { Compressive strength } \\
\left(\mathbf{N} / \mathbf{m m}^{2}\right)\end{array}$ & $\begin{array}{c}\text { Cost } \\
(\mathbf{R s})\end{array}$ \\
\hline ALC bloks & 1611 & $7-10$ & 30 \\
\hline Solid blocks & 2210 & $2-3$ & 24 \\
\hline Aerocon blocks & 820 & $3-4$ & 65 \\
\hline
\end{tabular}

\section{Conclusions}

Based on the investigation, the following conclusions were drawn.

- It is possible to produce aerated concrete with strength up to $25 \mathrm{MPa}$ by partially replacing cement with fly ash and GGBS up to $25 \%$. Also the densities of aerated concrete were in the range of $1600-1400 \mathrm{~kg} / \mathrm{m}^{3}$.

- By varying quantity of $\mathrm{Al}$ powder, density and compressive strength of aerated concrete decreased with the increase in $\mathrm{Al}$ content (for more than $0.5 \%$ replacement of cement).

- When the fly ash and GGBS content was increased in the mix, the density of aerated concrete decreased due to the low specific gravity of fly ash and GGBS as compared to cement.

- By adopting the method of partial replacement of cement by admixtures, the cost of preparation of aerated blocks can be greatly reduced as compared to other commercially available blocks.

- Fly ash and GGBS used as admixtures enables the large utilization of waste product, which can reduce energy costs in processing of natural materials, reduced land disposal and reduced greenhouse gases.

\section{References}

[1] Javier PinillaMelo, Alberto Sepulcre Aguilar, Francisco Hernández Olivares, Rheological Properties of Aerated Cement Pastes with Fly Ash, Metakaolin And Sepiolite Additions, Construction and Building Materials, Vol. 65, 2014, pp 566-573.

[2] PawełWalczaka, PawełSzymański, AgnieszkaRóżycka, Autoclaved Aerated Concrete Based on Fly Ash in Density 350 Kg/m ${ }^{3}$ as an Environmentally Friendly Material for Energy -EfficientConstructions, ProcediaEngineering,Vol. 122, 2015 , pp39 - 46.

[3] R. Arellano Aguilar, O. Burciaga Diaz, J.I. Escalante Garcia, Lightweight concretes of activated metakaolin - fly ash binders, with blast furnace slag aggregates, Construction and Building Materials, Vol. 24, 2010, pp 1166-1175.

[4] RostislavDrochytkaa, Ji riZacha, AzraKorjenicb, JitkaHroudovaa, Improving the energy efficiency in buildings while reducing the waste using autoclaved aerated concrete made from power industry waste, Energy and Buildings, Vol. 58, 2013 , pp319-323. 
[5] Jihad Hamad Mohammad, Ali Jihad Hamad, A classification of lightweight concrete: materials, properties and application review, International Journal of Advanced Engineering Applications, Vol 7,2014, pp 52-57.

[6] Abdullah K., M. W. Hussin, F. Zakaria, R. Muhammad, Z. Abdul Hamid, "POFA- A potential partial cement replacement material in aerated concrete," Proceedings of the 6th Asia Pacific Structural Engineering and Construction conference, Malaysia, 2006.

[7] IS 1077 : 1992 "Common burnt clay building bricks - specification", Bureau of Indian Standards, New Delhi, 2002

[8] IS: 2185 (part-I) 1979, "Specifications for concrete masonry units-part I Hollow and Solid Concrete Blocks", (Second Revision). 